\title{
SUSTAINABLE LOGISTICS RELATED TO GREEN INITIATIVE
}

\author{
Milla Amanda ${ }^{1}$, Novyana Evalinda ${ }^{2}$, Yuda Yulianto ${ }^{3}$ \\ 1. STMT Trisakti, 2. STMT Trisakti, 3. Universitaet Duisburg-Essen \\ $\checkmark$ corresponding authors: millaamandamilla@gmail.com
}

\begin{abstract}
In this age, transportation and technology are rapidly advencing. Innovations continue to take place in every new invention. Unfortunately, public awareness is often not in line with the balance between the ecosystems and the environment. This causes the issue of global warming. One of the main factors in terms of the global warming issue is the lack of attention to exhaust gases generated by production and supply activities. Many contemporary production and supply activities cause $\mathrm{CO}_{2}$ and environmental pollution. This regards to this phenomena, we will discuss the problem of pollution caused by production and supply activities. The article we are writing may still need revision and may still be lacking in data management due to time limitation. Findings : The data we have collected comes from 1. WRI-Indonesia (WRI Indonesia is an independent research organization that turns big ideas into action at the nexus of environment, economic opportunity, and human well-being), , and 2. books and journals related to this topic. Originality/value: This study examinise the impacts of production and supply activities on the enviromental issues. Furthermore, this paper will be discussing the efforts to reduce gas emissions or energy consumption. Keywords Logistics: Eco green initiative, Gas Emission, Energy Consumption, Production and Supply Activities.
\end{abstract}

\section{Introduction}

Why is the principle of eco or green activity very important nowadays? Green activity itself is any movement that can help reduce the warming of the earth. This phenomenon is caused by the condition of the earth that heats up from year to year. The ozone layer is getting thinner and thinner. Why is the principle of eco or green activity so important today that green activity itself is any movement that can help reduce the warming of the earth? This is caused the earth heats up from year to year. This warming causes the depletion of the ozone layer, which, as we know is the same ozone layer that protects us from UVA and UVB rays generated by sunlight. UVA and UVB rays are the triggers of skin cancer and skin tissue damage as well as other problems. If left unresolved, this condition will be harmful to the earth where we live, as well as to all living things on earth, triggering 
the depletion of ozone. One of the factors that cause the depletion of ozone is the amount of $\mathrm{CO}_{2}$ (carbon dioxide) gas in the air.

This gas is mostly produced by the burning of oil from fossils of things that lived in ancient times. Researchers have explored the benefits of fossil fuels and have discovered that the oil from the rest of the decay of fossils that were buried millions of years ago could serve to power a machine.

This discovery was the start of the era of gasoline-fueled transportation (fossil oil), which was first patented in 1879 by Karl Benz (November 25, 1844 - April 4, 1929). Since that time the production process and activity of supply of fossil fuel have continued. This has caused the earth to heat up more, while there is continuous demand for oil drilling on a larger scale. On the other hand, oil drilling will not last long as petroleum supply will also be depleted in the next few years. $\mathrm{CO}_{2}$ in the air will cause the decrease of the ozone layer event and made the Earth more heat, worsening global warming. Therefore, the authors would like to adress this problem by writing an article, which presents the data of exhaust emissions in Indonesia that contributes to the increase of $\mathrm{CO}_{2}$ in the air. The authors hope that with article will help readers and practitioners in industry to contribute to reduce $\mathrm{CO}_{2}$ emissions in the air.

In addition to producing $\mathrm{CO}_{2}$ which is a major component of global warming, poor production processes can also damage the environment. Poor production and improper waste disposal can also damage the environment. By implementing these green initiatives, companies can certify that the products they manufacture are environmentally friendly. Regrattably only a number of companies apply this method to support the process of green initiative for which they are awarded the ISO 14000 certificate.

With an ISO 14000, a company is confirmed to have supported the action of green initiatives by conducting production activities and good waste handling. The products produced by certified companies will be accepted world wide because countries especially developed nation, only accept products of a company that has an ISO 14000 certificate. 
As a result, companies that have not been certified ISO 14000 will lose competitiveness with environmentally friendly products that are produced by certified companies. Their products can be exported to all countries in the world. Thus, it will be of great benefit to apply green initiatives in life as well as in the production and waste management processes in a company.

\section{Method}

\section{Descriptive Research}

The authors have used Descriptive Research Method because it is used to describe the characteristics of the population or phenomenon being studied. It does not answer questions about how/when/why the characteristics occurred. Rather, it addresses the "what" question (what are the characteristics of the Minnesota state population or situation being studied?). The characteristics used to describe the situation or population are usually some kind of categorical scheme also known as descriptive categories. For example, the periodic table categorizes the elements. Scientists use knowledge about the nature of electrons, protons and neutrons to devise this categorical scheme. Descriptive research generally precedes explanatory research.

\section{Discussion and Result}

\section{Production}

The main concept about production in logistics is about understanding the impact of customized logistical designs on overall performance. (University of Twente). The reason why production concept have to be learned in the beginning of this syncronized system is because production is the first activity of the supply chain. The break downs of production we will discuss are energy consumption, material selection, and waste. The table below is data consisting of the number of the use of vehicle or transportation mode in Jakarta from 2009 to 2012.

Table 1: http://www.vedcmalang.com/pppptkboemlg/index.php/menuutama/otomotif/999-sasongko1

\begin{tabular}{|c|c|c|c|c|c|}
\hline No. & Type & 2009 & 2010 & 2011 & 2012 \\
\hline 1 & Car & 7.910 .407 & 8.891 .041 & 9.548 .866 & 10.432 .259 \\
\hline 2 & Buss & 2.160 .973 & 2.250 .109 & 2.254 .109 & 2.273 .821 \\
\hline 3 & Truck & 4.452 .343 & 4.687 .789 & 4.958 .738 & 5.286 .061 \\
\hline 4 & Motor Cycle & 52.767 .093 & 61.078 .188 & 68.839 .341 & 76.381 .183 \\
\hline & Total & $\mathbf{6 7 . 2 9 0 . 8 1 6}$ & $\mathbf{7 8 . 9 0 7 . 1 2 7}$ & $\mathbf{8 5 . 6 0 1 . 0 5 4}$ & $\mathbf{9 4 . 3 7 3 . 3 2 4}$ \\
\hline
\end{tabular}




\section{Energy Consumption}

Distillation systems are energy and power intensive processes and contribute to greenhouse gas emissions (e.g. carbon dioxide). Reducing $\mathrm{CO}_{2}$ emissions is an absolute necessity and an expensive challenge to the chemical process industries in order to meet the environmental targets as agreed in the Kyoto Protocol.

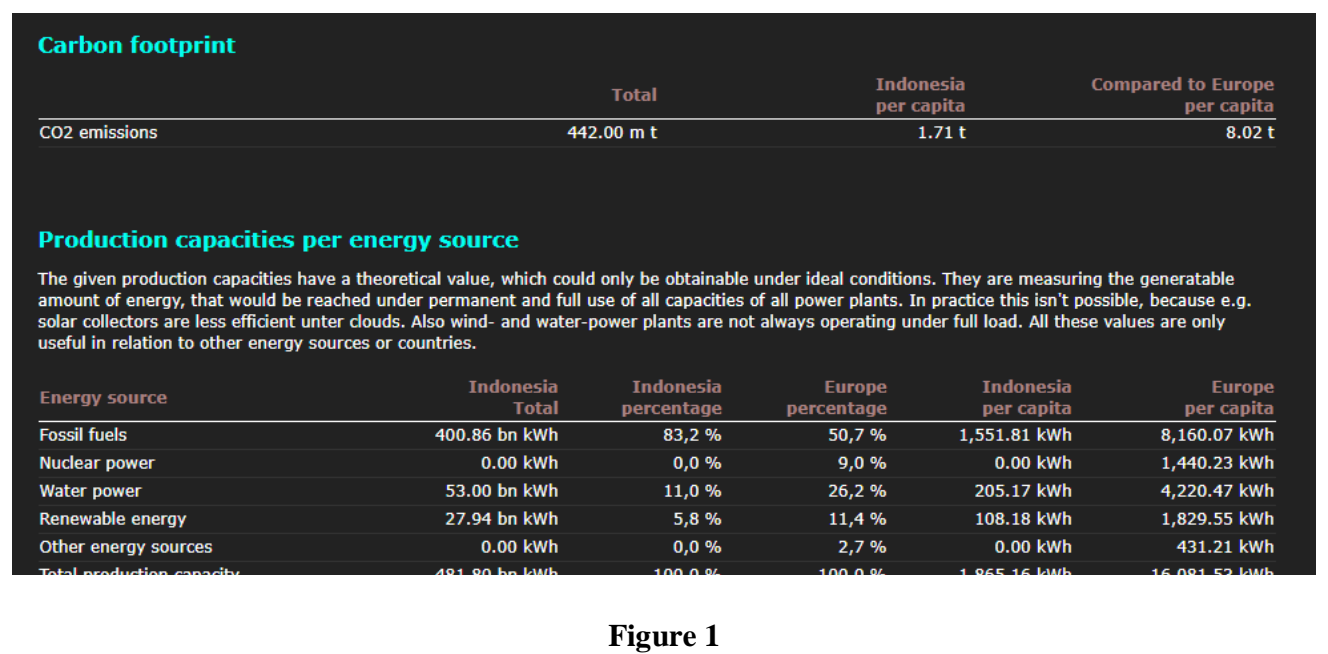

\section{Energy Consumption in Indonesia}

Total energy consumption in Indonesia is 195.00 billion $\mathrm{kWh}$ per year, which per capita on average is $755 \mathrm{kWh}$. Besides, Indonesia is able to provide our own needs of energy. It is reported that over all energy production in Indonesia is 216 bn $\mathrm{kWh}$, which is $111 \%$ of the actual need.

\section{Reducing $\mathrm{CO}_{2}$ Emissions and Energy Consumption of Heat- integrated Distillation Systems.}

The Distillation System can cause considerable energy and power intensive effects on the process of reducing carbon dioxide $\left(\mathrm{CO}_{2}\right)$ in green initiatives. In reducing $\mathrm{CO}_{2}$ emissions, it is absolute and a challenge for industry players that produce chemical processes to set environmental targets as agreed in the Kyoto Protocol conferences. 
In this case, a simple model for calculating $\mathrm{CO}_{2}$ emissions comes from heat-integrated distillation systems which are usually use by industries, considering the usefulness of the devices. Devices include, for example, Boilers, Furnaces and Turbines. Furnaces and turbines produce electrical power by using large amounts of fuel. As a result, they release large $\mathrm{CO}_{2}$ gas into the air. The same goes for Boilers, which produce steam for the purpos of heating. In addition, they produce a lot of gas emissions.

These models can be used to optimize the mining and oil industry processes in order to reduce $\mathrm{CO} 2$ emissions in the air, along with other energy needs.

It can also be an option for industries to determine their most suitable design to reduce $\mathrm{CO}_{2}$ emissions. This process can be applied to reduce larger gas emissions and can save on sustainable energy. Research results show that by installing crude oil, an industry can reduce gas emissions by $21 \%$ for energy and $22 \%$ for the emissions when the condition of the process and production are categorized as optimal. The condition can be practically optimal if the process involves the integration of the gas turbine, then the gas emissions can be reduced by as much as $48 \%$. Implementation of this system can give companies more benefits, save costs and minimizes gases emissions.

\section{Material Selection}

Inventory is needed because to procure goods, lead time need to be considered for the booking process item. So when there are some demand in an enterprise, then the requested items which is expected to come can be filled immediately upon demand the goods. (Zaini, 2014)

The selection of raw materials is the most important part in producing a product. The process of selecting raw materials is also important to achieve successful competitiveness among producers. The wrong selection of raw materials can lead to the destruction of a product, and make a negative impact on the production process within the company. Research has proven that choosing raw materials with a variety of requirements and backgrounds supports green initiatives, green 
manufacturing, and increases market demand today, because all countries need environmentally friendly products.

For example, the use of wood in the manufacture of furniture includes three commonly used materials namely, A beech wood desk (P1), A white oak-and-fabric sofa (P2), A rubber wood wardrobe (P3). According to LCA results, P1 is the most environmently friendly material because it has the smallest negative environmental impact (22.1 pt) through its life cycle P2 (57.3 pt) and P3 (142 pt). The production of wooden material proved to be the "hot spot" process, which contribute $68 \%, 50 \%, 88 \%$ respectively to the total impact of the three subjects.

\section{Packaging Design}

Eco Design strategy has suggested to reduce residual materials and support green initiative in the environment of a production system. All things that come from them can be grouped according to the stage of the life cycle of packaging they have been subjected to (Crul and Diehl 2006, van Hemel 1998). Furthermore, in this section we will discuss more in depth the selection and collection of echo design strategies that can be applied to packaging, which later can be recycled and be more environmentally friendly.

Here is an example, the use of environmentally friendly packaging is $\mathrm{La}$ Mâche Nantaise. La Mache Nantaise has created a new breakthrough in the field of packaging design, in the form of an environmentally friendly thin plastic fold to wrap the salad and covered with stickers made from cardboard wax. This wax carton serves to hold moisture in its contents.

\section{Waste}

Waste is a product that has achieved its final goal in its use during the life of a product. And waste is also a waste of the production process. But these wastes were once just wasted and piled up somewhere. From the whole, only a small part of the material can be reprocessed in the life cycle production. For example, a gold ring weighing 10 grams can produce 3 tons of waste (Von Weizsckerat al 1997: 242). This is commonly referred to as the ecological footprint of a product. 
ISO's Related to this point are:

- ISO 14 040:2006 Environmental management - Life cycle assessment - Principles and framework

- ISO /TR 14047:2003 Environmental management - Life cycle impact assessment - Examples of application of ISO 14042

- ISO /TR 14 049:2000 Environmental management - Life cycle assessment - Examples of application of ISO 14041 to goal and scope definition and inventory analysis. (M, Nath and Architecture, 2000)

\section{Inbound Transportation}

One of the growing problems of firms in developing countries is the related delivery problem at the time and accuracy of the 6R objectives of logistics. This problem has been answered in developed countries by applying Justin-Time (JIT) practices. This practice focuses on reducing stock inventory levels, thereby reducing overhead costs and optimizing the use of resources to manage existing inventory (Toke, Gupta and Dandekar, 2010), for example, the quantity of goods to be carried from the inventory or warehouse to the destination. When the company delivers in small quantites, it means there will be more deliveries.

Factors that are linked to JIT and supplier management are usually preplanned load forecasting in demand levels that can be implemented in numbers. In this "trade-off" process, there are a number of problems, such as with the consolidation of goods. Waiting time for delivery to full load will lead to lead time, but, on the other hand, such a process can increase savings and is more environmentally friendly. Another problem that must be faced also in the process is choosing a vehicle.

The selection of a carrier is one of the important in-bound logistics processes. The reason is that carrier determination can affect the next process in an industry. For example, a small community business unit, in an attempt to open an online store, would prefer to use inexpensive logistics carriers for special items in a single shipment for a large amount. 
There are so many things to be evaluated to choose the right transport mode based on the company needs, for example like the need of time, need of budget or cost, need of distance, and etc. Carrier selection, a part of the supplier selection, is an important in-bound logistics decision. Transportation is important to all industries. As an example, the Chemical Manufacturers Association cited Roadway Express, a major carrier, as a responsive care partner in hauling chemicals.

In fact, in the transport sector, transportation accounts for $23 \%$ of the world's greenhouse gas emissions caused by fossil fuels. Of the total greenhouse gas emissions, road transportation accounts for $75 \%$, which can lead to uninterrupted $\mathrm{CO} 2$ gas growth. Of course, this involves the government in issuing policies for the use of fuel that produces gas emissions for optimal use.

Statistical data show that more than $90 \%$ of total road transportation still uses fuel oil to operate. This has caused similar demand for world oil which has reached $60 \%$. Because of this, we provide a solution for the efficient use of fuel by replacing these fuels with gas or sunlight.

\section{Routing and Load Optimization \\ Routing}

The definition of routing is selecting the minimum cost, distance, and/or time path from several alternatives for a good or message to reach its destination. Basic theories of vehicle routing are Travel Salesman Problem and Vehicle Routing Problem. Reducing the use of fuel can be done by routing vehicle approach by not forgetting the objectivities of the logistics. $\left(6^{\text {th }} \mathrm{R}\right.$ 's are right product, right quantity, right condition, right place, right time, right cost). The whole process of shipping goods can use the transport fleet and it is imperative for the courier to know the route. (Lasse and Darunanto, no date)

\section{Load Optimization}

Load optimization and eco green are related to the load that has been set and does not exceed, (not overloaded) because the continuous use of a road by 
trucks with excessive load will reduce the age of the highway and cause holes in the road (Sugiyanto, 2002) . Growth of freight traffic, especially trucks carrying raw materials / finished goods, has caused the problem of overloading.

\section{Warehousing}

The optimum storage will be achieved if supported by several factors, such as qualified human resources, sufficient facilities and infrastructures, procedures and forms that manage the storage activities, as well as the proper condition of place/warehouse.(Rachmat, no date)

\section{Sustainable Warehousing}

Warehousing is one of the most important parts in the logistics process in an industry, because the warehouse contributes $24 \%$ of the logistics costs. Warehouse is known as the storage of

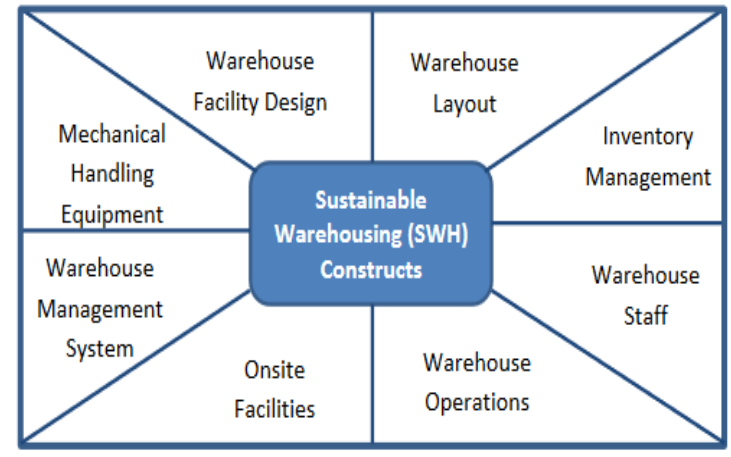
materals, both raw materials, semi-finished materials, and Figure 2 finished goods.

Usually the environmental balance in warehousing is given attention to. However, this article will be give examples of reducing energy consumption in warehousing : reducing toxic materials, reducing the use of energy for packaging (electricity), reuse of recyclable waste, use of more environmentally friendly energy (e.g. solar thermal energy for daytime warehouse lighting), using environmentally friendly raw materials. 


\section{Saving on Warehouse Energy Consumption}

Many benefits can be generated if we apply green initiative practices. One of them is the warehouse. This is not only saves energy, but also saves warehouse cost, which has a good impact on the environment.

Here are some ways to save on warehousing. First, Replace the roof of your warehouse. Usually older buildings tend to use heavier and cooler roof tiles. However, there is a ways to replace roof tiles with lightweight steel, which will make the warehouse warmer and the roof last longer. Getting more natural light. Replace some of your roof with a roof of fiber composition. This will make the warehouse brighter during the day (natural light). Replace your lamp with a more energy efficient lamp. Because nowadays, companies engaged in the production of lamps have been producing LED lights that are more energy saving and more environmentally friendly. Use the lights as efficiently as possible in the places needed only. Use Programmable Thermostats. The warehouse that uses these Thermostats will better know which zones need to be warmed up, or what temperature to set. Using a warehouse vehicle. Use for example forklift that no longer uses gasoline as fuel, but is operated by electrical energy.

\section{Outbound Transportation}

In outbound transportation there are several areas that must be considered based on existing standards that have a relationship in the implications of green initiatives. Logistic network design and planning are strategies that must be prepared by the logistics manager for the smooth outbound logistics process. Many decisions are made for the satisfaction of the parties

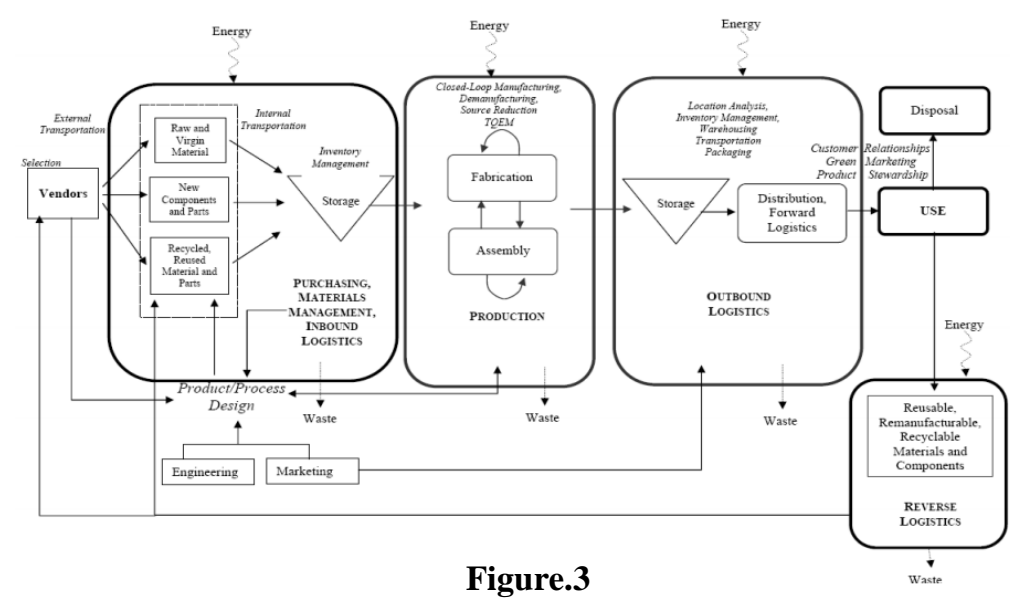


concerned. Besides that, outbound transportation also handles the movement of goods from manufacture to customer. Actually, the logistics company uses more than one mode to deliver the goods. Using more than one mode of transportation is called multimoda transportation. Multimodal transport is a key component that plays an important role in supporting the logistics system chain ( $\mathrm{S}$, no date).

Examples of decision making taken from several options are direct delivery or huband spokes for the development of a distributed network or central warehouse, a third party service or a private intermodal or single mode fleet. Some examples of design criteria and management that should be considered for smooth and good planning are number of shipping, handling method, route selection and good space utilization. An important issue in the outbound logistics process (and also inbound) is warehousing and packaging shipping design. Warehouse design, operational cost savings, recyclable packaging, and easy access to information are things that are include the practice of other green initiatives. The utilization of consolidation and breakbulk operations conducted in a warehouse will be beneficial in a more efficient transport capacity.

\section{Retail}

\section{Green Package}

According to its definition, green package requires more pollution prevention. Therefore, the product will less harmful to the environment. This concept is to talk about the design of the energy factor in the output and may be in the temporary reduction. The essennce of the packaging function should also be retained, ie the protection of the contents of package, the use of a good method, the quality of the service itself, the quality of the package and the cost that will have to be issued.

An example is the Clever Little Bag from Puma, a simple but innovative shoe packaging that eliminates the need for laminate printing, tissue paper and a plastic carrying bag (Techeblog, 2012). According to Puma (2012), each year, its design saves 8,500 tons of paper, 20 
million Megajoules of electricity, 1 million liters of fuel oil, 1 million liters of water, half a million liters of diesel transport oil and 275 tons of plastic. In 2011, Puma won the Good Design award for innovative packaging design.

\section{Reverse Logistics}

Reverse logistics is defined as a term usually used to refer to the role of logistics in return of a product which can be re-processed, which can also play a role in product recycling, substitution, reuse of materials, and waste disposal, as well as improvements manufactur (Toke, Gupta \& DandekaISr, 2010). For example, Firm named Sinar Sosro is participating in this reverse logistics by producing their product of tea, then packaged in bottle which material has been built by shards. They distribute their product to customers with concept their of getting the bottle back to be refilled.

\section{Last Mile to Customer}

In this part, we will talk about how to deliver the goods to the customer. Points we will talk about are Driving Training and Delivery Concept. Some points which were already explained in previous part are Type of Vehicle and Route and Load Optimization (Inbound and Outbound Transportation).

\section{Driver Training}

Driver training is one of the most important steps in the logistics system, which also contributes to green initiative. Training programs conducted by the company should be done in a planned, directed, and dynamic way so as to improve the ability, operational performance, dedication, and loyalty. (Lasse and Darunanto, no date) This training is needed because in the future the potential driver will face various problems in on the journey from the origin to the destination. First, the candidate is in training within a certain period, in order to comply with traffic regulation, reduce accidents and other things that are not desirable. The part that must be trained in the delivery of materials and simulation is 
the path that has been determined, how to drive well and follow the rules that are on traffic signs, and to recognize the dangers in driving, as well as other important information.

\section{Driving Simulation}

The driver must be trained in accordance with the standards that exist in a company. such as training in controling the vehicle, in using the handbrake and drive properly, and knowing how to apply the GPS, so that he will be able to drive well in accordance with the existing rules. (within the agency).

\section{Delivery Concept}

Delivery Concept means how to transport or deliver customer's goods to the determined place with Logistics Concept, $6^{\text {th }} \mathrm{R}$ 's which are right product, right quantity, right condition, right place, right time, right cost. This means that a good delivery concept planning motivates the company to be a green initiative participant which has already been explained in Routing and Load Optimization. An examples is Pizza Hut Delivery, which their objective and marketing slogan "Received in 30 minutes". It means that your order will be received at your place in good condition in 30 minutes. Or, if it is more than the estimated time, Pizza Hut Delivery will gives you some additional offers such payment discount, additional food, additional drink, etc.

\section{Conclusion}

We have reviewed numbers of explainations about upgrading green initiative in production and supply activities to support better life in the future. These functions include, production, inbound and outboud transportation, warehousing, retail and last mile to customer. The supporting examples which can be implemented are already explained in each point of function. We feel that in the future, the topic of this study will be discussed and debated a lot and may be applied in reality because its main objective to save the world. Technologies might help, but taking control of balancing the echosystem is our responsibility. Sustainable logistics for sustainable life. 


\section{References}

Amjed, T. W., \& Harrison, N. J. (2013). a Model for Sustainable Warehousing: From Theory To Best Practices. Retrieved from http://gebrc.nccu.edu.tw/proceedings/APDSI/2013/proc/P130212001.p df

Lasse, D. and Darunanto, D. (no date) 'BAGI ANAK BUAH KAPAL', pp. 257-266.

M, A. R., Nath, R., \& Architecture, P. (2000). Environmental Management. Iso,2009, 6, 217-224. https://doi.org/10.1080/00382167.1994.9629674

M, A. R., Nath, R. and Architecture, P. (2000) 'Environmental

Management', Iso,2009, 6, pp. 217-224. doi:

10.1080/00382167.1994.9629674.

Qi, Z., Xilong, J., \& Weiqiong, H. (2011). A research into the tendency of green package design. Communications in Computer and Information Science, 234 CCIS(PART 4), 219-223. https://doi.org/10.1007/978-3642-24091-1_30

Rachmat, R. D. (no date) 'Study on The Cause of Stock Out of Logistic Installation in Harapan Kita Hospital', 2(1), pp. 79-92.

Reducing $\mathrm{CO} 2$ emissions and energy consumption of heat-integrated distillation systems. Authors: Mamdouh A. Gadalla,Zarko Olujic,Peter J. Jansens, Megan Jobson, Robin Smith

Shields, Patricia and Rangarajan, N. 2013. A Playbook for Research Methods: Integrating Conceptual Frameworks and Project Management. Stillwater, OK: New Forums Press. See Chapter 4 for an in-depth discussion of descriptive research.

S, T. I. H. (no date) 'Multimoda Dalam Mewujudkan Visi Logistik Indonesia 2025', pp. 69-84.

Toke, L. K., Gupta, R. C. and Dandekar, M. (2010) 'Green Supply Chain Management; Critical Research and Practices', Proceedings of the 2010 International Conference on Industrial Engineering and Operations Management, Dhaka, Bangladesh, pp. 9-10.

Transportasi, M. B. (n.d.). Optimasi beban as truk untuk meminimalkan biaya transportasi, 1-12.

Zaini, M. (2014) 'Analisis Pengendalian Persediaan Raw Material Spark Plugs Pada Pt Denso Indonesia Jakarta Tahun 2014’, pp. 21-33.

https://www.utwente.nl/en/education/master/programmes/industrialengineering-management/specialization/production-and-logisticmanagement/

https://www.worlddata.info/asia/indonesia/energy-consumption.php

https://www.conserve-energy-future.com/modes-and-benefits-of-greentransportation.php

http://www.earthtimes.org/green-blogs/green-living/save-warehouseenergy-consumption-21-Aug-12/ 